\title{
Analisis Gaya Bahasa pada Syair Sidang Fakir Empunya Kata Karya Hamzah Fansuri
}

\author{
Firdaus Aritonang ${ }^{* 1}$, Helvina Vardila ${ }^{2}$, Irene Ketrin ${ }^{3}$, Trisnawati Hutagalung ${ }^{4}$ \\ Universitas Negeri Medan \\ Jurusan Bahasa dan Sastra Indonesia, Fakultas Bahasa Seni, Medan \\ ${ }^{1}$ firdausaritonang806@gmail.com, ${ }^{2}$ helvinavardila5@gmail.com, ${ }^{3}$ ketrinirene3@ gamil.com, \\ trisnawati.hutagalung@yahoo.co.id
}

\begin{abstract}
Abstrak
Bahasa adalah alat yang dipakai untuk membentuk pikiran dan perasaan, keinginan dan perbuatan-perbuatan, alat yang dipakai untuk mempengaruhi dan dipengaruhi. Bahasa adalah alat komunikasi antaranggota masyarakat berupa lambang bunyi yang dihasilkan oleh alat ucap manusia. Pengertian bahasa itu meliputi dua bidang Pertama, bunyi yang dihasilkan oleh alat ucap dan arti atau makna yang tersirat dalam arus bunyi itu sendiri. Bunyi itu merupakan getaran yang merangsang alat pendengaran kita. Kedua, arti atau makna, yaitu isi yang terkandung di dalam arus bunyi yang menyebabkan adanya reaksi terhadap hal yang kita dengar. Guntur Tarigan, 2009: 4. Mengemukakan bahwa gaya bahasa merupakan bentuk retorik, yaitu penggunaan kata-kata dalam berbicara dan menulis untuk meyakinkan atau mempengaruhi penyimak atau pembaca. Tulisan ini berusaha mengkaji gaya bahasa yang terdapat dalam bahasa indah dalam menyampaikan pikiran dan perasaan yang digunakan dalam Syair Sidang Fakir Empunya Kata Karya Hamzah Fansuri Penelitian ini menggunakan penelitian kualitatif deskriptif. karena peneliti ingin menggambarkan atau melukiskan fakta-fakta atau gaya bahasa yang terdapat dalam Syair Sidang Fakir Empunya Kata Karya Hamzah Fansuri Penelitian deskriptif kualitatif adalah penelitian yang menggambarkan atau melukiskan objek penelitian berdasarkan fakta-fakta yang tampak atau sebagaimana adanya. Untuk itu penelitian ini akan menyajikan lebih dalam bagaimana gaya bahasa dalam Syair Sidang Fakir Empunya Kata Karya Hamzah Fansuri
\end{abstract}

Kata Kunci : Kualitatif deskriptif, Gaya Bahasa, Syair Sidang Fakir Empunya Kata.

\section{PENDAHULUAN}

Bahasa merupakan komponen terpenting dalam kehidupan manusia. Manusia tidak akan bisa melanjutkan kelangsungan hidup mereka dengan baik dan teratur tanpa adanya bahasa. Mereka tidak bisa berinteraksi dengan mudah dan baik jika mereka tidak menguasai bahasa antara satu sama lain dan dengan tidak adanya kesinambungan tersebut mereka juga tidak dapat menangkap ekspresi kejiwaan maupun keinginan yang diutarakan oleh lawan komunikasinya. Hal ini juga yang menyebabkan adanya sekat 
dan kurang terkaitnya emosional satu sama lain.

\section{Keraf dalam Smarapradhipa}

(2005): memberikan dua pengertian bahasa. Pengertian pertama menyatakan bahasa sebagai alat komunikasi antara anggota masyarakat berupa simbol bunyi yang dihasilkan oleh alat ucap manusia. Kedua, bahasa adalah sistem komunikasi yang mempergunakan simbol-simbol vokal (bunyi ujaran) yang bersifat arbitrer.

Chaer dan Agustina (1995:14) fungsi utama bahasa adalah sebagai alatkomunikasi. Hal ini sejalan dengan Soeparno (1993:5) yang menyatakan bahwafungsi umum bahasa adalah sebagai alat komunikasi sosial. Sosiolinguistik memandang bahasa sebagai tingkah laku sosial (sosial behavior) yang dipakaidalam komunikasi sosial.

Pada penelitian ini yang akan di bahas adalah bagaimana gaya bahasa pada Syair Sidang Fakir Empunya Gaya bahasa adalah bahasa indah yang digunakan untuk meningkatkan dengan jalan memperkenalkan serta membandingkan suatu benda atau hal tertentu dengan benda atau hal lain yang lebih umum (Tarigan, $2013: 4)$.

\section{KAJIAN TEORI}

Gaya bahasa merupakan susunan perkataan yang terjadi karena perasaan yang timbul atau hidup dalam hati penulis, yang menimbulkan suatu perasaan tertentu dalam hati pembaca (Pradopo, 2009: 93). Tarigan (1986:5) Gaya bahasa adalah bahasa yang indah yang dipergunakan untuk meningkatkab efek dengan jalan memperkenalkan serta memperbandingkan suatu benda atau hal tertentu dengan benda atau hal lain yang lebih umum.

Gaya atau khususnya gaya bahasa dikenal dalam retorika dengan istilah style. Kata style diturunkan dari kata latin stillus, yaitu semacam alat untuk menulis pada lempengan lilin. Keahlian menggunakan alat ini akan mempengaruhi jelas tidaknya tulisan pada lempengan tadi. Kelak pada waktu penekanan dititik beratkan pada keahlian untuk menulis indah, maka style lalu berubah menjadi kemampuan dan keahlian untuk menulis atau mempergunakan kata-kata secara indah. Pemilihan gaya bahasa ini benar-benar diperhatikan oleh pengarang sebab pengarang mengetahui bahwa hal itu akan memberikan nilai tersendiri baginya dan karyanya. Nilai yang diperoleh itu dapat berupa nilai estetis, yaitu keindahan yang akan mendayagunakan karya sastra itu sendiri.

Dari pendapat para ahli di atas, dapat disimpulkan bahwa gaya bahasa 
adalah cara pengarang menyampaikan/ mengungkapkan pikiran melalui bahasa yang indah dan biasanya digunakan untuk meningkatkan (keindahan) dari suatu karya sastra. Anggapan itu dituangkan dalam konteks tertentu, oleh orang tertentu, dan untuk maksud tertentu, serta mampu memberikan kesan suasana yang menyentuh daya emosi pembaca. Gaya bahasa akan mendapat reaksi yang berupa tanggapan dari pembaca atau pendengar.

Para peneliti mencari data dengan menggunakan metode metode penelitian kualitatif deskriptif karena peneliti ingin menggambarkan atau melukiskan faktafakta atau gaya bahasa yang terdapat dalam Syair Sidang Fakir Empunya Kata Karya Hamzah Fansuri Penelitian deskriptif kualitatif adalah penelitian yang menggambarkan atau melukiskan objek penelitian berdasarkan fakta-fakta yang tampak atau sebagaimana adanya. . Untuk itu penelitian ini akan menyajikan lebih dalam bagaimana gaya bahasa dalam Syair Sidang Fakir Empunya Kata Karya Hamzah Fansuri.

Pada penelitian ini yang akan di bahas adalah bagaimana gaya bahasa pada Syair Sidang Fakir Empunya Kata Karya Hamzah Fansuri Gaya bahasa adalah bahasa indah yang digunakan untuk meningkatkan dengan jalan memperkenalkan serta membandingkan suatu benda atau hal tertentu dengan benda atau hal lain yang lebih umum (Tarigan, $2013: 4)$.

Menurut penjelasan Harimurti Kridalaksana (Kamus Linguistik (1982), gaya bahasa (style) mempunyai tiga pengertian, yaitu:

1. Pemanfaatan atas kekayaan bahasa oleh seseorang dalam bertutur atau menulis.

2. Pemakaian ragam tertentu untuk memperoleh efek-efek tertentu.

3. Keseluruhan ciri-ciri bahasa sekelompok penulis sastra

Jenis-Jenis Gaya Bahasa Perbandingan Yang Terdapat Pada Syair Sidang Fakir Empunya Kata Karya Hamzah Fansuri

1. Gaya bahasa Hiperbola

Gaya bahasa Hiperbola yaitu mengungkapkan sesuatu dengan kesan berlebihan, bahkan hampir tidak masuk akal.Gorys Keraf (2004:141) menyatakan bahwa hiperbola adalah gaya bahasa yang mengandung suatu pernyataan yang berlebihan, dengan membesarbesarkan sesuatu hal.

\section{Gaya Bahasa Simile}

Gaya bahasa Simile adalah gaya bahasa perbandingan yang bersifat 
langsung dan implisit dengan mempergunakan kata-kata tugas tertentu sebagai penanda keimplisitan. Gorys Keraf (2004:139) menyatakan bahwa simile adalah perbandingan yang bersifat secara langsung menyatakan sesuatu sama dengan hal yang lain. Kata-kata yang biasanya digunakan antara lain: seperti, bagaikan, laksana, sama, dan sebagainya.

\section{Gaya Bahasa Personifikasi}

Gaya bahasa ini seakan menggantikan fungsi benda mati yang dapat bersikap layaknya manusia. Personifikasi adalah semacam gaya bahasa kiasan yang menggambarkan benda mati atau barang yang tak bernyawa seolah-olah dapat bertingkah laku seperti manusia Gorys Keraf (2004:142).

\section{Gaya Bahasa Metafora}

Gaya bahasa Metafora yaitu meletakkan sebuah objek yang bersifat sama dengan pesan yang ingin disampaikan dalam bentuk ungkapan. Keraf (2004: 139), berpendapat bahwa metafora adalah semacam analogi yang membandingkan dua hal secara langsung, tetapi dalam bentuk yang singkat.

Gaya bahasa sangat penting dalam suatu karya sastra, khususnya syair, gaya bahasa yang ada di dalam karya secara tidak langsung memberikan efek yang sangat besar. Pemilihan bentuk bahasa yang digunakan pengarang akan berkaitan fungsi dan konteks pemakaiannya. Pemakaian gaya bahasa dalam suatu syair selalu dikaitkan dengan konteks yang melatar belakangi pemilihan dan pemakaian bahasa. Semua gaya bahasa itu berkaitan langsung dengan latar sosial dan kehidupan di mana bahasa itu digunakan.

\section{Definisi Syair}

Syair adalah salah satu puisi lama. Syair berasal dari Persia, dan dibawa masuk ke Nusantara bersama dengan masuknya Islam ke Indonesia. Kata atau istilah Syair berasal dari bahasa arab yaitu Syi'ir atau Syu'ur yang berarti perasaan yang menyadari, kemudian kata Syu'ur berkembang menjadi Syi'ru yang berarti puisi dalam pengetahuan umum. Dalam kamus bahasa Indonesia, syair adalah puisi lama yang tiap-tiap bait terdiri atas empat larik (baris) yang berakhir dengan bunyi yang sama; sajak; puisi. Menurut KBBI, Pengertian Syair adalah puisi lama yang tiap-tiap baitnya terdiri atas empat larik (baris) yang berakhir dengan bunyi yang sama.

Dari beberapa bentuk sastra lama, syair merupakan bentuk sastra klasik melayu yang sudah mendekati kepunahan akibat tergerus zaman. Pada zaman modern seperti sekarang ini jarang sekali 
kita temukan pelaksanaan upacara adat yang masih menggunakan syair sebagai lantunan yang mengiri upacara-upacara adat yang ada di Indonesia.

Terdapat empat hal yang menjadi aspek di dalam makna yakni:

1. Pengertian (sense) Sense berarti hubungan antara bahasa dengan dunia kenyataan manusia. Banyak kata dalam sebuah bahasa maknanya tidak biasa diungkapkan secara mendalam karena suatu kata mempunyai keterbatasan menjelaskan diri . kondisi inilah yang sering melahirkan diskomunikasi antara penerima pesan dengan pengirim pesan.

2. Nilai Rasa (Feeling) Berbahasa pada dasarnya berhubungan dengan perasaan. Arti, pada saat kita mengucapkan kata-kata mempunyai nilai rasa bagi orang yang menangkap pesan itu. Hal ini tergantung dari pembicara dengan pendengar dan kata-kata yang di ujarkan.

3. Nada (Tone) Nada dalam bahasa dapat bermakna sikap/ tinggi nadanya suara dalam menyampaikan informasi. Aspek makna jenis ini lebih banyak dinyatakan oleh hubungan antara pembicara dengan pendengar, antara penulis dengan pembaca. Hubungan tersebut menentukan sikap yang tercermin dalam katakata yang digunakan sehingga muncullah yang disebut nilai rasa.

4. Maksud (Intention) Aspek makna tersebut merupakan maksud senang atau tidak senang efek usaha keras yang dilaksanakan. Biasanya ketika menyatakan sesuatu ada maksud yang diinginkan. Apakah kata itu bersifat deklaratif, imperatif, naratif, pedagogis, persuasive, rekreatif atau politis, semuanya mengandung maksud tertentu.

Menurut KBBI (Kamus Besar Bahasa Indonesia) syair adalah puisi lama yang tiap bait terdiri atas empat larik yang berakhir dengan bunyi yang sama. Orang yang membacakan syair atau membuat syair disebut penyair atau pujangga. Syair seperti dalam pengertiannya adalah bentuk yang terikat, sehingga ia mempunyai aturan-aturan tersendiri. Beberapa aturan yang mengikat suatu karya sastra disebut syair diantaranya adalah Terdiri dari empat baris setiap baitnya, Terdiri dari bait-bait yang bermakna isi, Jumlah kata setiap baris tetap biasanya 4-5 kata, Jumlah suku kata dalam setiap baris tetap yaitu 8-12 suku kata, Mempunyai rima yang tetap aa-a-a atau a-b-a-b dan Bahasa kiasan. 
Syair ini berasal dari melayu dan Hamzah Fansuri lah yang kebanyakan berkontribusi dalam pembuatan syair khas melayu. Banyak sekali macam-macam syair dalam sastra, diantaranya adalah syair panji, syair kiasan, syair romantis, syair sejarah, dan syair agama. Pada penelitian ini yang di bahas adalah syair agama, syair agama adalah syair yang menceritakan mengenai agama. Syair agama yang di teliti berjudul Analisis Gaya Bahasa Pada Syair Sidang Fakir Empunya Kata Karya Hamzah Fansuri.

\section{METODE PENELITIAN}

Metode pengumpulan data yang digunakan dalam penelitian ini menggunakan jenis penelitian kualitatif deskriptif. Metode kualitatif deskriptif menyesuaikan pendapat antara peneliti dengan informan. Rancangan penelitian deskriptif kualitatif dipilih karena cocok dengan karakteristik masalah penelitian dan membuat deskripsi yang sistematis dan akurat mengenai gaya bahasa dalam "Gaya Bahasa pada Syair Sidang Fakir Empunya Kata Karya Hamzah Fansuri". Pengumpulan data dilakukan dengan mengambil objek Syair Sidang Fakir Empunya Kata Karya Hamzah Fansuri yang mengandung gaya bahasa tertentu. Teknik pengumpulan data yang digunakan dalam penelitian ini adalah studi pustaka dengan cara membaca dan mencatat datadata berupa baris syair yang mengandung gaya bahasa.

\section{Sumber data penelitian}

Sumber data yang dilakukan dalam penelitian ini yaitu sumber data sekunder merupakan sumber data tidak langsung. Sumber data yang digunakan dalam penelitian ini adalah dokumentasi dan studi kepustakaan dengan bantuan media cetak dan media internet serta catatan penelit

\section{Instrumen Penelitian}

Dalam penelitian ini peneliti bertindak sebagai instrument sekaligus pengumpul data. Peneliti berhubungan langsung dengan teks Syair Sidang Fakir Empunya Kata Karya Hamzah Fansuri sebagai sumber data. Adapun instrument lain yang dibutuhkan untuk meununjang kelancaran penelitian ini berupa alat tulis untuk mencatat hal-hal yang terkait dengan penelitian dan laptop yang berisi teks Syair Sidang Fakir Empunya Kata Karya Hamzah Fansuri,

Instrumen merupakan alat pada waktu peneliti menggunakan suatu metode (Suharsimi,1993: 168). Instrumen dalam penelitian ini antara lain

1. Peneliti sendiri (human instrument) Peneliti dengan segala 
pengetahuannya berusaha

mendiskripsikan gaya bahasa yang ada pada Syair Sidang Fakir Empunya Kata Karya Hamzah Fansuri.

2. Mengumpulkan data, mencatat data yang di cari yaitu gaya bahasa dan melakukan pengecekkan kembali terhadap Syair Sidang Fakir Empunya Kata Karya Hamzah Fansuri,

3. Mengklasifikasikan data berupa Syair Sidang Fakir Empunya Kata Karya Hamzah Fansuri, berdasarkan jenis gaya bahasa yang terkadung dalam syair tersebut.

\section{Teknik Pengumpulan Data}

Setelah mengetahui sumber-sumber bahan bacaan, pengumpulan data dilakukan dengan dua teknit yaitu:

1. Teknik Simak

Metode simak adalah metode yang digunakan untuk memperoleh data dengan menyimak penggunaan bahasa. Dinamakan metode simak karena cara yang digunakan untuk memperoleh data yaitu dengan cara menyimak penggunaan bahasa (Mahsun, 2007 : 29). Metode ini digunakan untuk mendapatkan data lisan,

2. Teknik Catat
Selain teknik simak. Peneliti juga menggunakan teknik catat. Teknik catat digunakan untuk mencatat Syair Sidang Fakir Empunya Kata Karya Hamzah Fansuri. Pencatatan dapat dilakukan pada kartu data yang telah disediakan atau akan disediakan. Setelah pencatatan dilakukan, peneliti melakukan klarifikasi atau pengelompokkan. Penggunaan teknik catat ini sangat fleksibel. Bila teknik sadap sebagai teknik dasar dengan teknik simak libat cakap sebagai teknik lanjutan digunakan, peneliti dapat langsung mencatat data yang diperoleh.

\section{Teknik Analisis Data}

Proses analisis data dimulai dengan menelaah seluruh data yang tersedia setelah dibaca, dipelajari dan ditelaah (Moleong, 2010:247). Adapun cara yang dilakukan oleh peneliti untuk menganalisis data sebagai berikut:

1. Pengumpulan Data Tahapan pertama untuk menganalisis data adalah tahap pengumpulan data. Seperti yang dikemukakan sebelumnya bahwa proses analisis data dilakukan sejak pengumpulan data dimulai. Setelah data diubah dalam bentuk tulisan pada tahap ini 
peneliti telah mendapatkan data mentah.

2. Reduksi Data Setelah data terkumpul, peneliti melakukan reduksi data dalam hal ini memilah data-data yang diperlukan untuk menjawab permasalahan penelitian tentang makana Syair Sidang Fakir Empunya Kata Karya Hamzah Fansuri, Penyajian Data Penyajian data merupakan tahap penjabaran setiap data yang diperoleh. Peneliti berusaha menjabarkan makna yang terdapat dalam Syair Sidang Fakir Empunya Kata Karya Hamzah Fansuri,

3. Verifikasi/penarikan kesimpulan Pada tahap ini peneliti melakukan verifikasi dan penarikan kesimpulan mengenai makna yang terkandung dalam Namun sebelum melakukan penarikan kesimpulan peneliti melakukan verifikasi berupa triangulasi data antar peneliti yang kompeten untuk menunjang validitas dan kualitas data yang diperoleh. Setelah melakukan verifikasi data, maka penelti dapat melakukan penarikan kesimpulan tentang makna Syair Sidang Fakir Empunya Kata Karya Hamzah Fansuri.

\section{HASIL DAN PEMBAHASAN}

Sesuai dengan judul penelitian ini yaitu "Analisis Gaya Bahasa pada Syair Sidang Fakir Empunya Kata Karya Hamzah Fansuri, maka peneliti akan membahas gaya bahasa apa saja yang digunakan dalam syair tersebut.

Pada Syair Sidang Fakir Empunya Kata Karya Hamzah Fansuri terdapat gaya bahasa Perbandingan, Jenis gaya bahasa ini merupakan gaya bahasa yang digunakan untuk menyandingkan atau membandingkan suatu objek dengan objek lain melalui proses penyamaan, pelebihan, ataupun penggantian. Pada Syair Sidang Empunya Kata Karya Hamzah Fansuri terdapat gaya bahasa Perbandingan, yaitu Hiperbola, Simile, Personifikasi dan Metafora.

\section{Gaya Bahasa Hiperbola pada Syair Sidang Fakir Empunya Kata Karya Hamzah Fansuri}

Gaya bahasa hiperbola adalah gaya bahasa yang mengandung suatu pernyataan yang berlebihan, dengan membesar-besarkan sesuatu hal. Berikut analisis bahasa hiperbola dalam Syair Sidang Fakir Empunya Kata Karya Hamzah Fansuri melalui bait-bait yang terdapat dalam syair.

\section{Contoh syair dengan gaya bahasa}

hiperbola 
Hapuskan akal dan rasamu

Lenyapkan badan dan nyawamu

Pejamkan hendak kedua matamu

di sana kau lihat permai rupamu

Syair yang berjudul Syair Sidang

Fakir Empunya Kata Karya Hamzah Fansuri ditemukan gaya bahasa hiperbola pada baris ke 4 bait ke 11 "di sana kau lihat permai rupamu ". Bermakna tentang keindahan wajah atau paras. Penyair sengaja mengambil gaya bahasa perbandingan ini supaya ia lebih mendapatkan nilai estetis dalam karyanya.

\section{Gaya Bahasa Simile pada Syair}

Sidang Fakir Empunya Kata Karya

\section{Hamzah Fansuri}

Gaya bahasa Simile adalah gaya bahasa perbandingan yang bersifat langsung dan implisit dengan mempergunakan kata-kata tugas tertentu sebagai penanda keimplisitan Kata-kata yang biasanya digunakan antara lain: seperti, bagaikan, laksana, sama, dan sebagainya. Berikut analisis bahasa simile dalam Syair Sidang Fakir Empunya Kata Karya Hamzah Fansuri melalui baitbait yang terdapat dalam syair.

\section{a. Contoh syair dengan gaya bahasa simile}

Hamzah miskin orang uryâ ni
Seperti Ismail menjadi qurbâni

Bukannya Ajam lagi Arab î

Senantiasa wâshil dengan Yang Bâ qî

Syair yang berjudul Syair Sidang Fakir Empunya Kata Karya Hamzah Fansuri ditemukan gaya bahasa simile pada baris ke 2 bait ke 13 adanya penggunaan kata "seperti". Hamzah miskin orang uryâ ni Seperti Ismail menjadi qurbâni. Gaya bahasa simile (perbandingan) tersebut adalah seperti, yang berarti Hamzah Fansuri mengumpamakan dirinya seperti Nabi Ismail yang dijadikan kurban karena keikhlasannya. Penyair sengaja mengambil gaya bahasa perbandingan ini supaya ia lebih mendapatkan nilai estetis dalam karyanya.

\section{b. Contoh syair dengan gaya bahasa simile}

Rupamu itu yogya kau serang

Supaya sampai ke negeri yang henang

Seperti Ali tatkala berperang

Melepaskan Duldul tiada berkekang

Syair yang berjudul Syair Sidang Fakir Empunya Kata Karya Hamzah 
Fansuri ditemukan gaya bahasa simile pada baris ke 3 bait ke 12 adanya penggunaan kata "seperti". Supaya sampai ke negeri yang henang Seperti Ali tatkala berperang. Gaya bahasa simile (perbandingan) tersebut seperti. yang berarti henang membinasakan keraguan yang ada pada dirinya sehingga mendapatkan tempat yang tetap dan segala sesuatu yang dapat mebinasakan dirinya seperti amirul-muminin yaitu Ali tatkala berperang. Penyair sengaja mengambil gaya bahasa perbandingan ini supaya ia lebih mendapatkan nilai estetis dalam karyanya.

\section{c. Contoh syair dengan gaya bahasa simile}

Kenal dirimu hai anak ratu
Ombak dan air asalnya satu

Seperti manikam much îth dan batu

Inilah tamtsil engkau dan ratu

Syair yang berjudul Syair Sidang Fakir Empunya Kata Karya Hamzah Fansuri ditemukan gaya bahasa simile pada baris ke 3 bait ke 5 adanya penggunaan kata "seperti". Ombak dan air asalnya satu Seperti manikam much îth dan batu. Gaya bahasa simile (perbandingan) tersebut adalah seperti, yang berarti Ombak berasal dari air sehigga ombak berasal dari yang satu yaitu air dan mengibaratkan makluk berasal dari wujud Allah yang satu seperti manikam much ith yang artinya mengumpamakan Allah dengan manikam bercahaya didalam batu. Penyair sengaja mengambil gaya bahasa perbandingan ini supaya ia lebih mendapatkan nilai estetis dalam karyanya.

\section{Gaya bahasa Personifikasi pada Syair Sidang Fakir Empunya Kata Karya Hamzah Fansuri}

Personifikasi adalah semacam gaya bahasa kiasan yang menggambarkan benda mati atau barang yang tak bernyawa seolah-olah dapat bertingkah laku seperti manusia. Berikut analisis bahasa Personifikasi dalam Syair Sidang Fakir Empunya Kata Karya Hamzah Fansuri melalui bait-bait yang terdapat dalam syair.

\section{a. Contoh syair dengan gaya bahasa personifikasi}

Kenal dirimu hai anak ratu

Ombak dan air asalnya satu

Seperti manikam much îth dan batu

Inilah tamtsil engkau dan ratu

Syair yang berjudul Syair Sidang Fakir Empunya Kata Karya Hamzah Fansuri ditemukan gaya bahasa Personifikasi pada baris ke 2 bait ke 5 adanya penggunaan kata "ombak dan air". Gaya bahasa metafora tersebut mengumpamakan semua 
makhluk dengan ombak dan negumpamakan allah dengan air sebagai asalnya. Berarti ombak berasal dari air dan kembali pun menuju air sehingga ombak berasal dari kesatuan, yaitu air. Penyair sengaja mengambil gaya bahasa perbandingan ini supaya ia lebih mendapatkan nilai estetis dalam karyanya.

\section{b. Contoh syair dengan gaya bahasa personifikasi}

Kenal dirimu hai anak ratu

Ombak dan air asalnya satu

Seperti manikam much îth dan batu

Inilah tamtsil engkau dan ratu

Syair yang berjudul Syair Sidang Fakir Empunya Kata Karya Hamzah Fansuri ditemukan gaya bahasa Personifikasi pada baris ke 3 bait ke 5 adanya penggunaan kata "much ith dan batu". Gaya bahasa metafora tersebut mengumpamakan makhluk dengan batu dan mengumpamakan allah Taala dengan manikam yang bercahaya di dalam batu. Penyair sengaja mengambil gaya bahasa perbandingan ini supaya ia lebih mendapatkan nilai estetis dalam karyanya.

\section{Gaya Bahasa Metafora pada Syair Sidang Fakir Empunya Kata Karya Hamzah Fansuri}

Gaya bahasa Metafora yaitu meletakkan sebuah objek yang bersifat sama dengan pesan yang ingin disampaikan dalam bentuk ungkapan. Berikut analisis bahasa Metafora dalam Syair Sidang Fakir Empunya Kata Karya Hamzah Fansuri melalui bait-bait yang terdapat dalam syair.

\section{a. Contoh syair dengan gaya bahasa metafora}

Kenal dirimu hai anak dagang

Menafikan dirimu jangan kau saying

Suluh itsbât yogya kau pasang Maka sampai engkau anak hulu baling

Syair yang berjudul Syair Sidang Fakir Empunya Kata Karya Hamzah Fansuri ditemukan gaya bahasa Metafora pada baris pertama bait ke 4 adanya penggunaan kata "anak dagang" yang artinya anak perantauan, di maksudkan sebagai anak rantau di dalam perjalanannya tidak akan dapat kembali ke negeri tempat asalnya. Penyair sengaja mengambil gaya bahasa perbandingan ini supaya ia lebih mendapatkan nilai estetis dalam karyanya.

\section{b. Contoh syair dengan gaya bahasa metafora}

Mencari dunia berkawan-kawan

Oleh nafsu khabî ts badan tertawan

Nafsumu itu yogya kau lawan

Maka sampai engkau bangsawan 
Syair yang berjudul Syair Sidang Fakir Empunya Kata Karya Hamzah Fansuri ditemukan gaya bahasa Metafora pada baris pertama bait ke 8 adanya penggunaan kata "berkawan-kawan" artinya bergerombol. Berarti siapapun manusia yang mencari kesenangan dunia secara berlebih-lebihan atau ingin memiliki harta benda secara berlebih-lebihan, mereka tidak akan dapat menempuh jalan menuju allah taala. Penyair sengaja mengambil gaya bahasa perbandingan ini supaya ia lebih mendapatkan nilai estetis dalam karyanya.

\section{c. Contoh syair dengan gaya bahasa metafora}

Hapuskan akal dan rasamu

Lenyapkan badan dan nyawamu

Pejamkan hendak kedua matamu

di sana kau lihat permai rupamu

Syair yang berjudul Syair Sidang

Fakir Empunya Kata Karya Hamzah Fansuri ditemukan gaya bahasa Metafora pada baris ke 4 bait ke 11 adanya penggunaan kata "permai" artinya elok. Berarti gaya bahasa metafora ini bermakna terlihat keelokan dan keindahan rupa dirinya. Keelokan dan keindahan rupa dirinya dipandang masih dalam kawasan ilmu allah taala artinya suci. Penyair sengaja mengambil gaya bahasa perbandingan ini supaya ia lebih mendapatkan nilai estetis dalam karyanya.

\section{d. Contoh syair dengan gaya bahasa metafora}

Rupamu itu yogya kau serang

Supaya sampai ke negeri yang henang

Seperti Ali tatkala berperang

Melepaskan Duldul tiada berkekang

Syair yang berjudul Syair Sidang Fakir Empunya Kata Karya Hamzah Fansuri ditemukan gaya bahasa Metafora pada baris ke 2 bait ke 12 adanya penggunaan kata "henang" artinya tetap tidak berpindah-pindah. Gaya bahasa metafora tersebut memiliki maksud orang yang telah menghilangkan keraguannya, prasangka buruk dan kebimbangan yang ada pada dirinya, niscaya mereka akan mendapatkan tempat yang tetap dan tidak berpindahpindah. Penyair sengaja mengambil gaya bahasa perbandingan ini supaya ia lebih mendapatkan nilai estetis dalam karyanya.

Dapat kita ketahui pada contoh diatas bahwa terdapat penggunaan gaya bahasa perbandingan yaitu Hiperbola, Simile, Personifikasi dan Metafora, Pada Syair Sidang Fakir Empunya Kata Karya Hamzah Fansuri dapat diketahui ada gaya bahasa Gaya Bahasa Hiperbola pada Syair yang berjudul Syair Sidang Fakir Empunya Kata Karya Hamzah Fansuri ditemukan gaya bahasa hiperbola pada baris ke 4 bait ke 11. Gaya bahasa Simile 
ditemukan pada Syair yang berjudul Syair Sidang Fakir Empunya Kata Karya Hamzah Fansuri pada baris ke 2 bait ke 13, pada baris ke 3 bait ke 12 dan pada baris ke 3 bait ke 5. Gaya bahasa Personifikasi ditemukan pada Syair yang berjudul Syair Sidang Fakir Empunya Kata Karya Hamzah Fansuri pada baris ke 2 bait ke 5 dan pada baris ke 3 bait ke 5. Gaya bahasa Metafora ditemukan pada Syair yang berjudul Syair Sidang Fakir Empunya Kata Karya Hamzah Fansuri pada baris pertama bait ke 4, pada baris pertama bait ke 8 , pada baris ke 4 bait ke 11 dan pada baris ke 2 bait ke 12 . Jadi terdapat 1 gaya bahasa Hiperbola, terdapat 3 gaya bahasa Simile, terdapat 2 gaya bahasa Personifikasi dan pada terdapat 4 gaya bahasa Metafora. Jadi lebih banyak gaya bahasa Metafora yang terdapat pada Syair Sidang Fakir Empunya Kata Karya Hamzah Fansuri. Pada syair terdapat contoh dan penjelasan agar pembaca dapat mengetahui dan menguraikan maksud dari makna yang terkandung dalam setiap bait syairnya berdasarkan gaya bahasa Hiperbole, Simile, Personafikasi dan Metafora, sehingga pembaca dapat memahami dan berpikir tentang pesanpesan atau nasehat yang dibuat penyair karya Hamzah Fansuri yang berjudul Syair Sidang Fakir Empunya Kata tersebut.

\section{SIMPULAN}

Berdasarkan hasil penelitian yang telah dilakukan dapat disimpulkan bahwa penelitian ini adalah penelitian yang menganalisis tentang gaya bahasa pada Syair Sidang Fakir Empunya Kata Karya Hamzah Fansuri, Penggunaan gaya bahasa dalam Syair sangat diperlukan karena bisa memberikan keindahan dalam suatu cerita agar memberikan suasana hidup dan menarik, sehingga meningkatkan minat pembaca dan memperkuat gagasan pembaca. Pada Syair Sidang Fakir Empunya Kata Karya Hamzah Fansuri terdapat Majas Perbandingan, Jenis majas ini merupakan gaya bahasa yang digunakan untuk menyandingkan atau membandingkan suatu objek dengan objek lain melalui proses penyamaan, pelebihan, ataupun penggantian.

Syair Sidang Fakir Empunya Kata Karya Hamzah Fansuri terdapat empat gaya bahasa yaitu gaya bahasa Hiperbola, Simile, Personifikasi dan Metafora. Berikut adalah hasil analisis peneliti terhadap gaya bahasa Syair Sidang Fakir Empunya Kata Karya Hamzah Fansuri.

1. Gaya Bahasa Hiperbola pada Syair yang berjudul Syair Sidang Fakir Empunya Kata Karya Hamzah Fansuri ditemukan gaya bahasa hiperbola pada baris ke 4 bait ke 
11 adanya kalimat di sana kau lihat permai rupamu.

2. Gaya bahasa Simile ditemukan gaya bahasa Syair yang berjudul Syair Sidang Fakir Empunya Kata Karya Hamzah Fansuri ditemukan gaya bahasa simile, pada baris ke 2 bait ke 13, pada baris ke 3 bait ke 12 dan pada baris ke 3 bait ke 5 adanya penggunaan kata "seperti".

3. Gaya bahasa Personifikasi ditemukan gaya bahasa Personifikasi pada Syair yang berjudul Syair Sidang Fakir Empunya Kata Karya Hamzah Fansuri ditemukan gaya bahasa pada baris ke 2 bait ke 5 dan pada baris ke 3 bait ke 5 adanya penggunaan kalimat ombak dan air dan much îth dan batu.

4. Gaya bahasa Metafora ditemukan gaya bahasa pada Syair yang berjudul Syair Sidang Fakir Empunya Kata Karya Hamzah Fansuri ditemukan gaya bahasa Metafora pada baris pertama bait ke 4, pada baris pertama bait ke 8 , pada baris ke 4 bait ke 11 dan pada baris ke 2 bait ke 12. adanya penggunaan kata anak dagang, berkawan-kawan, permai dan henang.

\section{SARAN}

Semoga penelitian ini dapat menginspirasi para peneliti lainnya untuk melanjutkan penelitian serupa di bidang lainnya. Penelitian ini dilakukan berdasarkan keinginan peneliti sendiri tanpa dorongan dari pihak manapun sehingga tulisan di dalam artikel ini adalah tulisan asli peneliti didukung dengan teoriteori para ahli. Untuk itu, jika terdapat kesalahan dalam penulisan agar dimalumi dan saransaran dari pembaca sangat dibutuhkan untuk perbaikan tulisan peneliti kedepannya.

\section{DAFTAR PUSTAKA}

Alwi, Hasan. 2011. Kamus Besar Bahasa Indonesia. Jakarta: Gramedia Pustaka Utama.

Arikunto, Suharsimi. 1993. Prosedur Penelitian Suatu Pendekatan Praktek. Yogyakarta: Rineka Cipta

Arikunto, Suharsimi .2017. Pengem bangan Instrumen Penelitian dan Penilaian Program. Yogyakarta: Pustaka Pelajar

Chaer, Abdul dan Leoni Agustina. 1995. Sosiolinguistik : Suatu Pengantar. Jakarta : Rineka Cipta

Keraf, Gorys. 2004. Diksi dan Gaya bahasa. Jakarta: Gramedia Pustaka Utama. 
Kridalaksana, Harimurti. 1982. Kamus

Linguistik. Jakarta: Gramedia Pustaka Utama.

Lexy J. Moleong, 2010: Metodologi Penelitian Kualitatif, Bandung: Remaja Rosda karya.

Mahsun. 2007. Metode Penelitian Bahasa. Jakarta: PT Raja Grafindo Persada.

Moleong, Lexy J. 2014. Metodologi Penelitian Kualitatif. Bandung: $\mathrm{Pt}$ Remaja Rosdakarya.

Smarapradhipa. 2005.

(http://winawimala.wordpress.com/a uthor/winawimala/). diakses tanggal 10 Januari 2012

Soeparno. 1993. Dasar-dasar Linguistik. Yogyakarta: Mitra Gama Widya Tarigan Henry Guntur. 1986. Pengajaran Gaya Bahasa. Bandung : Angkasa Bandung

Tarigan, H. G.(2013). Berbicara sebagai suatu keterampilan berbahasa. Bandung: Angkasa. 